\title{
Bone Marrow Mesenchymal Stem Cells-Derived Exosomal miR-425-5p Inhibits Acute Myeloid Leukemia Cell Proliferation, Apoptosis, Invasion and Migration by Targeting WTAP [Retraction]
}

\author{
Zhang L, Khadka B, Wu J, et al. Onco Targets Ther. 2022;14:4901-4914.
}

The Editor and Publisher of OncoTargets and Therapy wish to retract the published article. Following a request from the authors to make extensive post-publication corrections, it became evident the findings within the article may be unreliable. When following up with the authors in regard to these corrections, the authors were unable to provide a satisfactory explanation for the corrections or adequate raw data for their study. The Editor determined the findings of the study were invalid and requested for the article to be retracted.

Our decision-making was informed by our policy on publishing ethics and integrity and the COPE guidelines on retraction.

The retracted article will remain online to maintain the scholarly record, but it will be digitally watermarked on each page as "Retracted".

\section{Publish your work in this journal}

OncoTargets and Therapy is an international, peer-reviewed, open access journal focusing on the pathological basis of all cancers, potential targets for therapy and treatment protocols employed to improve the management of cancer patients. The journal also focuses on the impact of management programs and new therapeutic agents and protocols on patient perspectives such as quality of life, adherence and satisfaction. The manuscript management system is completely online and includes a very quick and fair peer-review system, which is all easy to use. Visit http://www.dovepress.com/testimonials.php to read real quotes from published authors. 